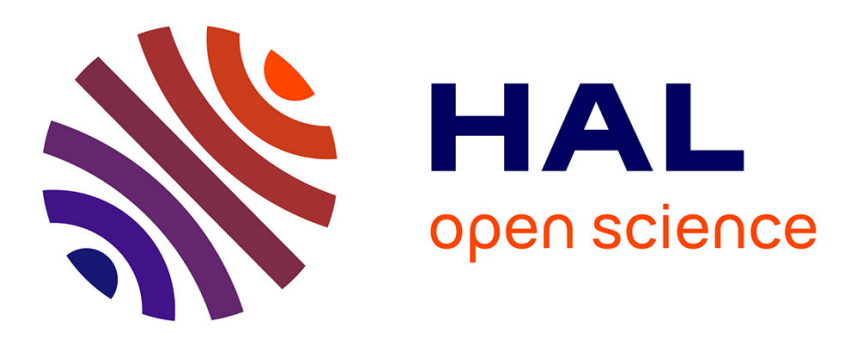

\title{
Thermoregulation, Hydration and Performance over 6 Days of Trail Running in the Tropics
}

Olivier Hue, Stéphane Henri, Michelle Baillot, Stéphane Sinnapah, André-Pierre Uzel

\section{- To cite this version:}

Olivier Hue, Stéphane Henri, Michelle Baillot, Stéphane Sinnapah, André-Pierre Uzel. Thermoregulation, Hydration and Performance over 6 Days of Trail Running in the Tropics. International Journal of Sports Medicine, 2014, 35, pp.906-911. 10.1055/s-0033-1361186 . hal-01135194

\section{HAL Id: hal-01135194 \\ https://hal.univ-antilles.fr/hal-01135194}

Submitted on 30 Mar 2015

HAL is a multi-disciplinary open access archive for the deposit and dissemination of scientific research documents, whether they are published or not. The documents may come from teaching and research institutions in France or abroad, or from public or private research centers.
L'archive ouverte pluridisciplinaire HAL, est destinée au dépôt et à la diffusion de documents scientifiques de niveau recherche, publiés ou non, émanant des établissements d'enseignement et de recherche français ou étrangers, des laboratoires publics ou privés. 


\section{Thermoregulation, Hydration and Performance over 6 Days of Trail Running in the Tropics}

Authors

Affiliations

\author{
O. Hue ${ }^{1}$, S. Henri ${ }^{1,2}$, M. Baillot ${ }^{1}$, S. Sinnapah ${ }^{1}$, A.-P. Uzel ${ }^{2}$
}

${ }^{1}$ Laboratoire ACTES, UPRES-EA 3596, UFR-STAPS, Université des Antilles et de la Guyane, Guadeloupe, France ${ }^{2}$ Service d'orthopédie et traumatologie du CHRU de Pointe-à-Pitre Route de Chauvel, 97159 Pointe-à-Pitre Cedex, Guadeloupe, France
Key words

- hot/wet climate

long-distance run

- self-hydration

accepted after revision

November 06, 2013

\section{Bibliography}

DOI http://dx.doi.org/

10.1055/s-0033-1361186

Published online:

May 19, 2014

Int J Sports Med 2014; 35:

906-911 @ Georg Thieme

Verlag KG Stuttgart · New York

ISSN 0172-4622

\section{Correspondence}

\section{Prof. Olivier Hue}

Laboratoire ACTES

Université des Antilles et de la

Guyane

Campus de Fouillole

97157 Pointe à Pitre

Guadeloupe

Tel.: + 590/690/55 1995

Fax: + 590/590/48 3179

olivier.hue@univ-ag.fr

\section{Abstract}

$\nabla$

The purpose of this study was to investigate thermal response, hydration and performance over a 6-day, $142-\mathrm{km}$ trail running race in tropical conditions. 9 participants competed in the 2011 Gwadarun $\left(30^{\circ} \mathrm{C} \pm 2.4^{\circ} \mathrm{C}\right.$ and $\left.82 \pm 4 \% \mathrm{RH}\right)$. Data were collected on days 1,4 and 6. Gastrointestinal temperature $\left(\mathrm{T}_{\mathrm{gi}}\right)$ and heart rate $(\mathrm{HR})$ were measured using portable telemetry units, whereas blood samples were collected for hematocrit, osmolarity, plasma concentrations, alkaline reserves and creatine phosphokinase. The performances expressed in speed were correlated with both total body water and body mass

\section{Introduction}

$\nabla$

Running, particularly long-distance running, is negatively affected by hot environments $[17,19]$. For example, marathon performance was shown to progressively slow as the wet bulb globe temperature (WBGT) index increased from 5 to $25^{\circ} \mathrm{C}$ [7]. This phenomenon is even more marked during running in a hot/wet climate (i.e., tropical climate [12]), which limits the evaporative processes $[12,18,38]$. Although the exact causes are not well known, explanations related to hyperthermia and/or dehydration have been proposed. During exercise, a large volume of sweat loss can gradually reduce blood and stroke volumes if not replaced, which tends to limit muscle blood flow [8]. If heat storage cannot be limited (because of the failure of evaporation processes), core temperature may limit exercise [9], or the brain may provoke a voluntary cessation of effort - or a reduction in its intensity - to maintain thermal homeostasis [23].

As pointed out by Maughan et al. [17], most of the data on the thermoregulatory response to exercise come from laboratory studies, with loss per hour (TBWL.h ${ }^{-1}$ and $\Delta$ BM.h ${ }^{-1}$ ), HR and changes in $\mathrm{T}_{\text {gi }}$ per hour $\left(\Delta \mathrm{T}_{\text {gi }} \cdot \mathrm{h}^{-1}\right)$ : the more water and mass the participants lost, the higher the HR and the greater the $\mathrm{T}_{\mathrm{gi}}$ change, and the better the performance. The $\Delta \mathrm{T}_{\text {gi }} \mathrm{h}^{-1}$ was significantly correlated with $\Delta$ BM. $\mathrm{h}^{-1}$, and the participants who lost the most mass had the greatest increases in $\mathrm{T}_{\text {gi. }}$. None of the blood parameters demonstrated significant changes. The present study showed that well-trained acclimated runners performing a 6-day trail race in a tropical environment and drinking ad libitum did not demonstrate heatrelated illness or severe dehydration. Moreover, high performance was associated with increases in $\mathrm{T}_{\mathrm{gi}}$, TBW and BM losses per hour.

fewer studies having focused on real-life situations. As the relationship between exercise and heat stress is currently a hot topic [34], the study of exercise performed in valid ecological conditions is particularly important to determine how the physiological response is affected [6]. Recently, the advent of ingestible sensors and data loggers has allowed sports scientists to measure core temperature during running competition in warm and humid conditions $[2,14]$. While these studies demonstrated high core temperature elevation without medical consequences and no detectable effects of the ingested fluid volume on any of the variables related to central temperature $\left(T_{C}\right)$ or performance, a relationship between running speed and $\mathrm{T}_{\mathrm{C}}$ increase was observed, with the best runners finishing with the highest $T_{C}$, as previously reported [25]. However, these results were obtained for relatively short-distance runs (i.e., $21 \mathrm{~km}$ ), in which runners can afford to take physiological risks in order to succeed $[2,14]$, and in high-level marathon runners $[28,37]$. For longer distances such as ultra-trail or multi-day trail runs, the relation- 
ship between $T_{C}$, hydration status and performance seems to be less clear [32].

The aim of the present study was to investigate the thermal response, hydration behaviour and performance during a 6-day, $142-\mathrm{km}$ trail race performed under tropical conditions.

\section{Material and Methods \\ V}

\section{Participants}

9 regionally- to internationally-ranked participants (8 males and 1 female; 0 Table 1) competed in the 2011 Gwadarun (a 6-day trail race covering the 6 islands of Guadeloupe, French West Indies: day 1: $27 \mathrm{~km}$, day 2: $27 \mathrm{~km}$; day 3: $15 \mathrm{~km}$; day 4: $15 \mathrm{~km}$; day 5: $25 \mathrm{~km}$ and day 6: $33 \mathrm{~km}$, for a total of $142 \mathrm{~km}$ under tropical conditions: $30 \pm 2.4^{\circ} \mathrm{C}$ and $82 \pm 4 \% \mathrm{RH}$ ). All participants gave written informed consent, and the protocol was approved by the ethics committee of the university and was conducted according to the Declaration of Helsinki. In addition, this study was performed in accordance with the ethical standard of the IJSM [11]. Participant characteristics are presented in 8 Table 1.

\section{Exercise intervention}

For the sake of the athletes' comfort, only trail days 1, 4 and 6 were studied. The sessions were performed in the early morning (starting at $7 \mathrm{am}$ ). Gastrointestinal temperature $\left(\mathrm{T}_{\mathrm{gi}}\right)$ was measured before and after each trail session with a CorTemp ${ }^{\mathrm{TM}} 2000$ ambulatory remote sensing system (HQ Inc., Palmetto, FL, USA), using pills that were given at least $3 \mathrm{~h}$ before each session. Heart rate (HR) was monitored continuously using a portable telemetry unit (Polar RS800SD, Polar Electro, Kempele, Finland) with recording every $5 \mathrm{~s}$. Body mass was assessed $( \pm 0.1 \mathrm{~kg})$ before and after the sessions (Planax Automatic, Teraillon, Chatoux, France). Lean body mass (LBM) was assessed from body weight and fat body mass as previously described [13]. The change in body mass, corrected for fluid intake and urine loss, but not accounting for metabolic fuel oxidation, metabolic water gain, or respiratory water losses, was used to estimate sweat loss. As no aid stations were used in the trail sessions, fluid intake during the race was estimated as the difference in backpack water weight (i.e., personal backpacks similar to the Camelbak ${ }^{\circledR}$ were used). The WBGT index was monitored for the duration of each session (QUESTemp ${ }^{\circ} 32$ Portable Monitor, QUEST Technologies, Oconomowoc, WI, USA).

Table 1 Anthropometric data for the 9 subjects.

\begin{tabular}{|llllll|}
\hline Subjects & $\begin{array}{l}\text { Age } \\
\text { Yrs }\end{array}$ & $\begin{array}{l}\text { Weight } \\
\text { kg }\end{array}$ & $\begin{array}{l}\text { Height } \\
\mathbf{m}\end{array}$ & $\begin{array}{l}\text { BFM } \\
\%\end{array}$ & $\begin{array}{l}\text { BSA } \\
\mathbf{m}^{2}\end{array}$ \\
\hline 1 & 36 & 66.5 & 170 & 8 & 1.78 \\
\hline 2 & 44 & 77.7 & 193 & 15 & 2.08 \\
\hline 3 & 49 & 61.2 & 180 & 11.2 & 1.78 \\
\hline 4 & 49 & 66 & 170 & 13.7 & 1.76 \\
\hline 5 & 64 & 73.2 & 180 & 15.6 & 1.92 \\
\hline 6 & 43 & 65.4 & 172 & 10 & 1.77 \\
\hline 7 & 52 & 68.3 & 183 & 14.6 & 1.88 \\
\hline 8 & 35 & 71.8 & 183 & 12.2 & 1.93 \\
\hline 9 & 47 & 55.5 & 161.5 & 15 & 1.57 \\
\hline Mean & 46.6 & 67.3 & 176.9 & 12.8 & 1.83 \\
\hline SD & 8.7 & 6.6 & 9.4 & 2.6 & 0.14 \\
\hline
\end{tabular}

\section{Blood analysis}

The day before T1 and immediately at the end of T6, blood samples were collected in tubes containing ethylenediaminetetraacetic acid (i.e., EDTA tubes). Hematocrit (Hct) was measured with a micro-method following blood microcentrifugation (16000 g, $10 \mathrm{~min}, 25^{\circ} \mathrm{C}$ ) (XE 2100, Sysmex, Kobe, Japan). The plasma concentrations in alkaline reserves (AR), proteins (Prot), sodium $\left[\mathrm{Na}^{+}\right]$, potassium $\left[\mathrm{K}^{+}\right]$, and creatine phosphokinase (CPK) were also measured at each sample time with a bench analyzer (Integra 800 Roche, Meylan, France). The plasma osmolarity was measured using an osmometer (Lôser, Fisher Scientific, Illkirch, France).

\section{Statistical analysis}

Each variable was tested for normality using the Skewness and Kurtosis tests, with acceptable $\mathrm{Z}$ values not exceeding +1 or -1 . Once the assumption of normality was confirmed, parametric tests were performed. The following variables: performance (Perf), $\mathrm{T}_{\mathrm{gi}}$, variation in $\mathrm{T}_{\mathrm{gi}}\left(\Delta \mathrm{T}_{\mathrm{gi}}\right)$, water intake $(\mathrm{WI})$, difference in body mass $(\triangle B M)$, total body water loss (TBWL) and $H R$, were analysed with a one-way analysis of variance (ANOVA) with repeated measures (trail day). Pairwise correlations were used to analyse the effect of variables on performance, water intake and $\mathrm{T}_{\mathrm{gi}}$ increase (BM, $\triangle \mathrm{BM}, \mathrm{WI}$, TBWL, lean body mass: $\mathrm{LBM}$, and body surface/weight ratio). Stepwise multiple linear regressions determined the best predictors of performance, water use and $\mathrm{T}_{\mathrm{gi}}$. Data are displayed as mean $\pm \mathrm{SD}$, and statistical significance was set at $p<0.05$. All statistics were computed using Systat $12^{\circledR}$ software.

\section{Results \\ $\nabla$}

\section{Changes in trail performance}

The mean performance for the 6-day trail race $\left(\right.$ Perf $\left._{6 \mathrm{~d}}\right)$ in terms of rank or \% of first place was not different among trail sessions ( $\bullet$ Table 2). However, both the time $(p<0.0001)$ and the mean speed $\left(\mathrm{m} . \mathrm{s}^{-1} ; p<0.02\right.$; $\odot$ Table 2 ) were significantly affected by the trail day. Although mean $\mathrm{T}_{\mathrm{gi}}$ and $\Delta \mathrm{T}_{\mathrm{gi}}$ did not change over the trail days, the $\mathrm{T}_{\mathrm{gi}}$ expressed in time unit $\left({ }^{\circ} \mathrm{C} \cdot \mathrm{h}^{-1}\right)$ demonstrated significant change $(p<0.05)$ across trail days ( $\bullet$ Table 2$)$. Weight loss $(p<0.0001)$, WI $(p<0.02)$ and TBWL $(p<0.0001)$ were significantly affected by the trail day when expressed in absolute values. Although WI expressed in time unit $\left(\mathrm{h}^{-1}\right)$ and weight loss expressed in time unit $\left(\mathrm{kg} . \mathrm{h}^{-1}\right)$ were not affected by trail day, both TBWL $(p<0.0001)$ and $\Delta \mathrm{T}_{\mathrm{gi}}(p<0.0001)$ expressed in time units were affected by the day. $\mathrm{HR}_{\text {mean }}$ was likewise affected by the trail day $(p<0.005)$.

\section{Global performance}

The Perf ${ }_{6 d}$ was significantly correlated with the cumulative performance on the 3 trail days studied $\left(R^{2}=0.98 ; p<0.001\right)$. When simple linear regressions were carried out, the performances expressed in speed on trail days 6 and $3\left(\operatorname{Perf}_{3 \mathrm{~d}}\right)$ were similarly correlated with: TBWL.h ${ }^{-1}\left(\mathrm{R}^{2}=0.61 ; p<0.02\right.$ and $\mathrm{R}^{2}=0.61$; $p<0.02) ; \Delta$ BM.h ${ }^{-1}\left(R^{2}=0.50 ; p<0.04\right.$ and $\left.R^{2}=0.48 ; p<0.04\right)$, $\mathrm{HR}_{\text {mean }}\left(\mathrm{R}^{2}=0.50 ; p<0.04\right.$ and $\left.\mathrm{R}^{2}=0.50 ; p<0.04\right)$ and $\Delta \mathrm{T}_{\mathrm{gi}} \mathrm{h}^{-1}$ $\left(\mathrm{R}^{2}=0.73 ; p<0.003\right.$ and $\left.\mathrm{R}^{2}=0.73 ; p<0.003\right)$ ( $\bullet$ Fig. 1). When stepwise multiple linear regression was applied, both Perf $_{6 \mathrm{~d}}$ and Perf $_{3 \mathrm{~d}}$ were significantly correlated with $\mathrm{HR}_{\text {mean }}$ and TBWL.h ${ }^{-1}$ : $\operatorname{Perf}_{6 \mathrm{~d}}\left(\mathrm{~m} . \mathrm{s}^{-1}\right)=0.023 \mathrm{HR}_{\text {mean }}-0.762 \mathrm{TBWL} . \mathrm{h}^{-1}-2.2 ;\left(\mathrm{R}^{2}=0.86\right.$; 
Table 2 Performance, core temperature (TC), change in TC (delta TC), body mass (BM) and body mass loss (BML), water intake (WI) and total body water loss (TBW) and heart rate (HR) during the 3 analysed trails and the final performance. a, b, c: significantly different from T1, T4 and T6, respectively.

\begin{tabular}{|c|c|c|c|c|c|c|}
\hline & & $\mathrm{T1}$ & T4 & T6 & Perf $_{6 d}$ & Mean \\
\hline \multirow[t]{4}{*}{ Performance } & $\mathrm{s}$ & $10534 \pm 2399 b c$ & $6123 \pm 1497 a c$ & $15413 \pm 4617 a b$ & $67096 \pm 17649$ & \\
\hline & rank & $13.9 \pm 9.3$ & $13.6 \pm 10.8$ & $14.8 \pm 10.5$ & $14.1 \pm 10.7$ & \\
\hline & $\%$ & $143.5 \pm 32.7$ & $139.3 \pm 34.0$ & $152.7 \pm 45.75$ & $142.6 \pm 37.5$ & \\
\hline & $\mathrm{m} \cdot \mathrm{s}^{-1}$ & $2.7 \pm 0.6$ & $2.6 \pm 0.6$ & $2.3 \pm 0.7 \mathrm{a}$ & $2.25 \pm 0.58$ & \\
\hline $\mathrm{T}^{\circ} \mathrm{C}$ & ${ }^{\circ} \mathrm{C}$ & $38.3 \pm 1.2$ & $38.7 \pm 0.7$ & $38.6 \pm 0.9$ & & $38.5 \pm 0.2$ \\
\hline \multirow[t]{2}{*}{ delta $\mathrm{T}^{\circ} \mathrm{C}$} & ${ }^{\circ} \mathrm{C}$ & $1.3 \pm 0.6$ & $1.8 \pm 0.6$ & $1.8 \pm 0.6$ & & $1.6 \pm 0.3$ \\
\hline & ${ }^{\circ} \mathrm{C} . \mathrm{h}^{-1}$ & $0.4 \pm 0.3$ & $1.1 \pm 0.5 \mathrm{ac}$ & $0.5 \pm 0.3$ & & $0.7 \pm 0.3$ \\
\hline \multirow[t]{2}{*}{ Delta BM } & $\mathrm{kg}$ & $-3.4 \pm 1.0$ & $-1.6 \pm 0.4 a$ & $-2.8 \pm 1.4 a$ & & $-2.6 \pm 0.7$ \\
\hline & $\mathrm{kg} \cdot \mathrm{h}^{-1}$ & $-0.6 \pm 0.2$ & $-0.7 \pm 0.7$ & $-0.7 \pm 0.3$ & & $-0.6 \pm 0.4$ \\
\hline BML & $\%$ & $5.1 \pm 1.4 \%$ & $2.4 \pm 0.7 \%$ & $4.0 \pm 1.5 \%$ & & $3.8 \pm 0.8 \%$ \\
\hline \multirow[t]{2}{*}{ WI } & $\mathrm{L}$ & $1.6 \pm 0.9$ & $1.1 \pm 0.7$ & $1.8 \pm 0.6 b$ & & $1.5 \pm 0.3$ \\
\hline & L.h h $^{-1}$ & $0.5 \pm 0.3$ & $0.6 \pm 0.3$ & $0.5 \pm 0.2$ & & $0.5 \pm 0.1$ \\
\hline \multirow[t]{2}{*}{ TBW } & L & $-5.0 \pm 1.1$ & $-2.9 \pm 3.2 \mathrm{ab}$ & $-4.6 \pm 1.3$ & & $-4.2 \pm 0.9$ \\
\hline & L.h h $^{-1}$ & $-1.8 \pm 0.6$ & $-1.6 \pm 0.4$ & $1.1 \pm 0.5 \mathrm{ab}$ & & $-1.7 \pm 0.9$ \\
\hline HR & bpm & $148 \pm 13$ & $147 \pm 12$ & $137 \pm 10 a b$ & & $144 \pm 5$ \\
\hline
\end{tabular}

$p<0.02)$ and $\operatorname{Perf}_{3 \mathrm{~d}}\left(\mathrm{~m} . \mathrm{s}^{-1}\right)=0.025 \mathrm{HR}_{\text {mean }}-0.792 \mathrm{TBWL} . \mathrm{h}^{-1}-2.13$; $\left(\mathrm{R}^{2}=0.74 ; p<0.02\right)$.

\section{Temperature}

The mean $\Delta \mathrm{T}_{\mathrm{gi}} \cdot \mathrm{h}^{-1}$ was not significantly and linearly correlated with TBWL.h ${ }^{-1}\left(\mathrm{R}^{2}=0.41 ; p<0.06\right)$ or $\mathrm{HR}_{\text {mean }}\left(\mathrm{R}^{2}=0.41 ; p<0.06\right)$, but was significantly correlated with $\Delta B M \cdot h^{-1} \quad\left(R^{2}=0.60\right.$; $p<0.02$; Fig. 2), Perf $6 \mathrm{~d}$ and $\operatorname{Perf}_{3 \mathrm{~d}}$. Stepwise multiple linear regression revealed that the best parameter correlated with $\Delta \mathrm{T}_{\text {gi }} \cdot \mathrm{h}^{-1}$ was $\operatorname{Perf}_{6 \mathrm{~d}} \quad\left(\Delta \mathrm{T}_{\mathrm{gi}} \cdot \mathrm{h}^{-1}=0.402 \operatorname{Perf}_{6 \mathrm{~d}}-0.304 ; \mathrm{R}^{2}=0.73\right.$; $p<0.003)$.

\section{Hydration}

The only parameter that tended to be significantly correlated with WI. ${ }^{-1}$ was $\mathrm{T}_{\text {gimean }}$ measured at the end of the trail sessions $\left(R^{2}=0.44 ; p<0.06\right)$. Stepwise multiple regression did not add better correlation. TBWL.h ${ }^{-1}$ was not significantly correlated with $\Delta \mathrm{T}_{\text {gi. }} \cdot \mathrm{h}^{-1}\left(\mathrm{R}^{2}=0.41 ; p<0.07\right)$ but was significantly correlated with both Perf ${ }_{6 \mathrm{~d}}$ and Perf ${ }_{3 \mathrm{~d}}$, as noted in the "global performance" chapter. Stepwise multiple linear regression did not demonstrate better correlation.

\section{Temperature/anthropometric characteristics}

None of the anthropometric parameters (BM, body surface/ weight ratio and LBM) were significantly correlated with the $\mathrm{T}_{\mathrm{gi}}$ changes across the trail sessions or $\mathrm{T}_{\mathrm{gi}}$ noted at the end of the sessions.

\section{Blood analysis}

We observed no significant changes in alkaline reserves, $\left[\mathrm{Na}^{+}\right]$, $\left[\mathrm{K}^{+}\right]$, proteins or osmolarity ( $\bullet$ Table 3 ). CPK was the only blood parameter that significantly changed ( $p<0.05$; $\bullet$ Table 3 ).

\section{Discussion}

$\nabla$

The most important findings of our study were that (1) performance was related to an increase in $\mathrm{T}_{\mathrm{gi}}$, a loss in both TBWL.h ${ }^{-1}$ and BM. $\mathrm{h}^{-1}$, and greater HR; (2) the increase in $\mathrm{T}_{\mathrm{gi}}$ was related to a decrease in BM; and (3) no heat stress was evidenced in any of the recruited participants.

\section{Fluid intake and sweat loss}

The water intake on the trails amounted to very little (i.e., around $0.5 \mathrm{~L} . \mathrm{h}^{-1}$ ), especially considering the tropical climate and the sweat loss rate (i.e., from 1.1 to $1.8 \mathrm{~L} . \mathrm{h}^{-1}$ ). However, this intake agrees with the American College of Sports Medicine [32] recommendations to drink 0.4 to $0.8 \mathrm{~L} . \mathrm{h}^{-1}$, depending on the runner's anthropometry and the intensity and distance of the event, and contradicts former guidelines that suggested drinking as much as possible to prevent dehydration [33]. Studies conducted in similar environments report similar data on water intake in mass-participation road races: Byrne et al. [2] noted a mean $0.37{\mathrm{~L} . \mathrm{h}^{-1}}^{-1}$ uring a $21-\mathrm{km}$ road race performed in $26.5^{\circ} \mathrm{C}$ WBGT, and Lee et al. [14] noted a mean $0.25 \mathrm{~L} \mathrm{~h}^{-1}$ during the same race 4 years later in conditions of $26.4{ }^{\circ} \mathrm{C}$ and $81 \% \mathrm{RH}$. Moreover, elite marathon runners showed similar intake (i.e., a mean $0.42{\mathrm{~L} . \mathrm{h}^{-1}}^{-1}$ extrapolated by Beis et al. [1] for the 2008 Beijing Olympic marathon.

The sweat loss rate of $1.1-1.8 \mathrm{~L}^{-\mathrm{h}^{-1}}$ was in the range of previous reports from studies performed in a tropical environment - that is, 1.47 L.h ${ }^{-1}$ for Byrne et al. [2] and 1.45 L.h ${ }^{-1}$ for Lee et al. [14]and, added to the water intake, induced a body mass loss of 2.4$5.1 \%$. This is considered to be beyond the normal TBWL fluctuation [3], and has been demonstrated to negatively affect endurance performance $[4,21]$. However, a decrease in performance due to dehydration has been shown in participants already dehydrated before the exercise $[4,5,21]$. In the present study, the participants began the trail sessions euhydrated (as reflected by the osmolarity before the sessions). However, since we did not collect urine or blood samples over the entire 6 days of the race, we cannot determine whether some of the participants were dehydrated for at least one of the trail races, with correspondingly decreased performances.

\section{Fluid losses and performance}

The 6-day performance was strongly and significantly correlated with the 3-day performance (i.e., the performances during the observed races), suggesting that the participants had neither an extraordinarily "bad" nor an extraordinarily "good" performance. This also suggests that some hypohydration was present to a similar degree in all the participants. Moreover, we found a significant correlation between the drops in both TBWL.h ${ }^{-1}$ and BM. $\mathrm{h}^{-1}$ and performance (i.e., the participants losing the most 


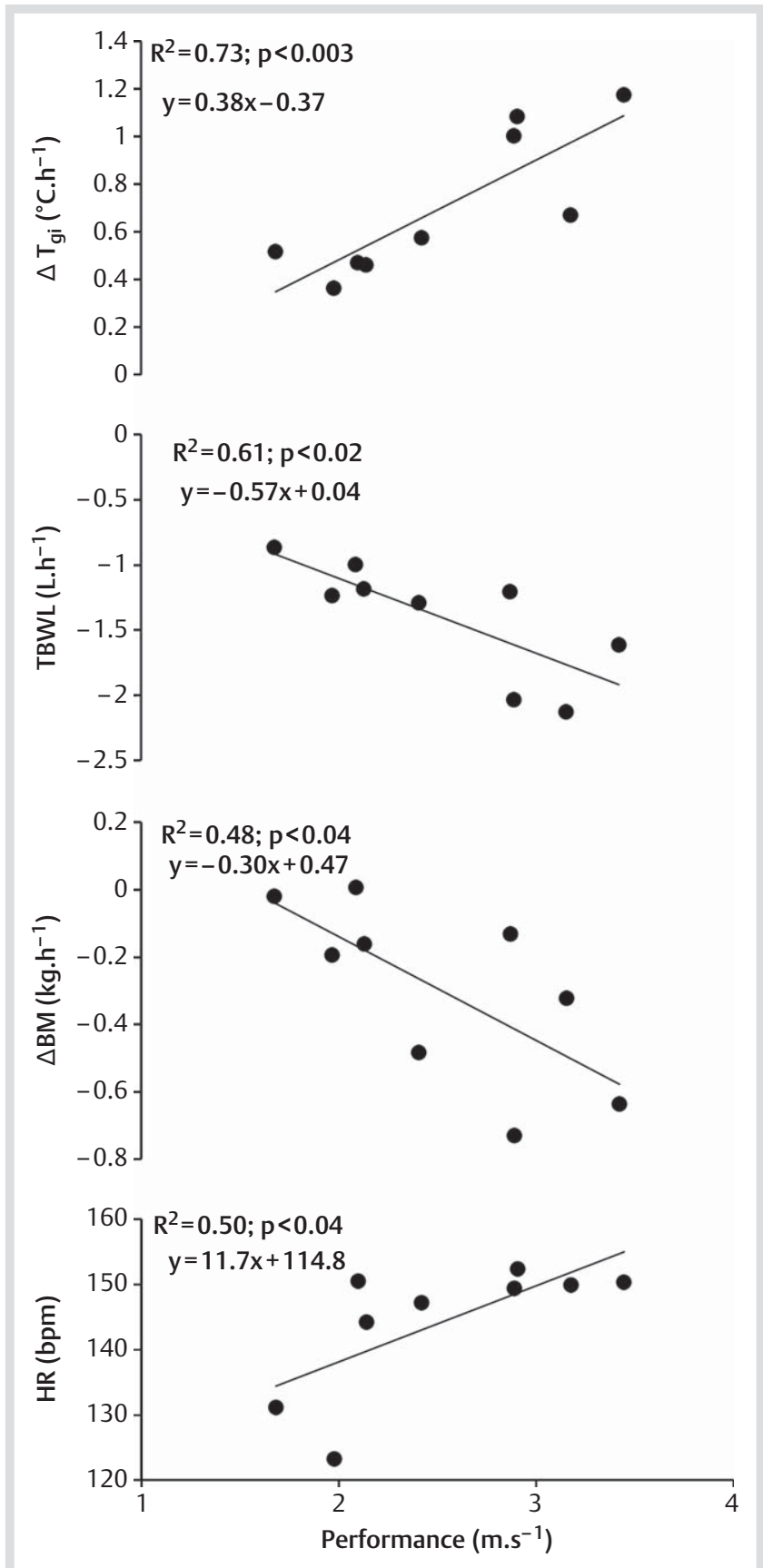

Fig. 1 Correlations between performance and delta temperature (delta $\mathrm{T}^{\circ} \mathrm{C}$ ), total body water loss (TBWL), delta body mass (delta BM) and heart rate.

water per hour and the most body mass were also the fastest). Such results have been noted during running and long-duration exercises, with the fastest finishers in endurance events often being the most dehydrated [33], and elite endurance athletes not appearing to drink very much during exercise $[1,22,37]$. Although all highly trained, the participants of the present study were clearly of mixed level, with some being internationally ranked. Therefore, the relationship between the losses in both TBWL and BM and performance would have to be seen as "the best and the best-trained runners losing the most TBWL and BM" and not "the more TBWL and BM runners lose, the faster they are", even though, as noted by Noakes [24], weight loss during the race is a good thing, as weight increases the running cost.

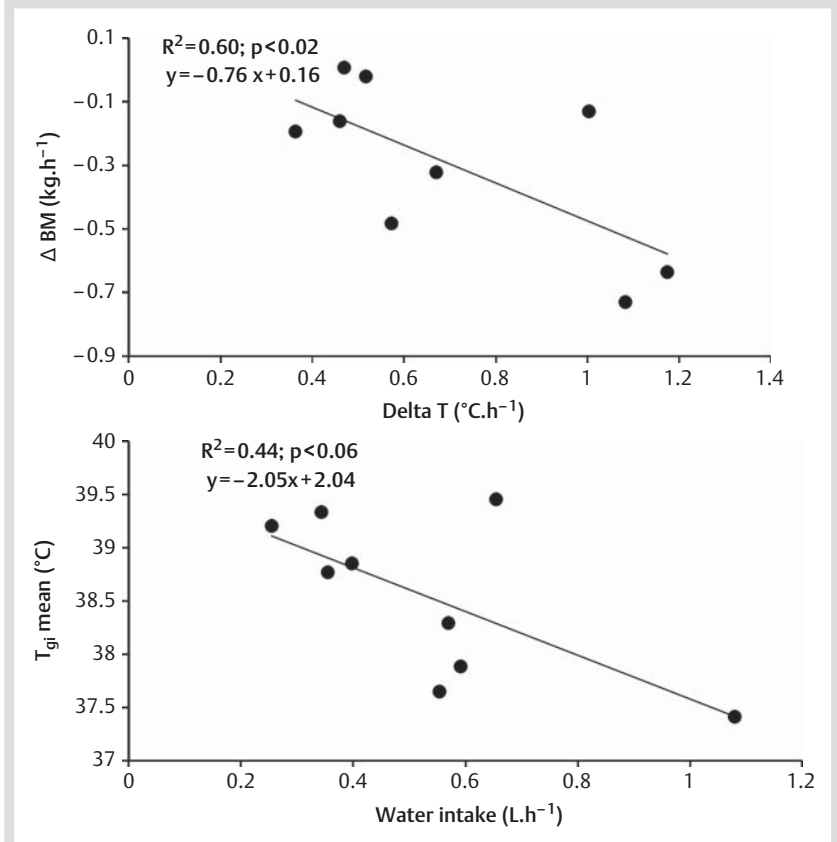

Fig. 2 Correlation between delta body mass (delta BM) and delta temperature (delta $\left.\mathrm{T}^{\circ} \mathrm{C}\right)$ and mean gastrointestinal temperature $\left(\mathrm{T}_{\mathrm{g}}\right.$ mean) and water intake.

Table 3 Alkaline reserves, proteins, sodium $\left[\mathrm{Na}^{+}\right]$, potassium $\left[\mathrm{K}^{+}\right]$, CPK and osmolarity, before and after the 6-days of trail running.

\begin{tabular}{|c|c|c|c|}
\hline & & Before & After \\
\hline alkaline reserves & mmol.t. & $27.3 \pm 2.5$ & $24.0 \pm 3.0$ \\
\hline proteins & $\mathrm{g} \cdot \mathrm{L}^{-1}$ & $67.2 \pm 2.7$ & $65.8 \pm 2.2$ \\
\hline $\mathrm{Na}+$ & mmol. $\mathrm{L}^{-1}$ & $139.7 \pm 1.6$ & $138.9 \pm 2.7$ \\
\hline $\mathrm{K}+$ & mmol. $\mathrm{L}^{-1}$ & $4.4 \pm 0.3$ & $4.9 \pm 0.4$ \\
\hline CPK & UI.L' & $184.9 \pm 137.7$ & $2128.6 \pm 1718.5^{*}$ \\
\hline osmolarity & $\mathrm{mOsm} \cdot \mathrm{L}^{-1}$ & $299.6 \pm 7.2$ & $303.8 \pm 8.0$ \\
\hline
\end{tabular}

${ }^{*} \mathrm{p}<0.05$, significantly different from before

\section{Intestinal temperature and performance}

The maximal average gastrointestinal temperature (38.3$38.7^{\circ} \mathrm{C}$ ) was lower than that noted by both Lee et al. [14] and Byrne et al. [3] (i.e., $39.8^{\circ} \mathrm{C}$ and $39.9^{\circ} \mathrm{C}$, respectively) during a $21-\mathrm{km}$ road run in tropical environment using ingestible telemetry sensors, and far from the rectal temperatures (40.0$42.0^{\circ} \mathrm{C}$ ) reported for heatstroke [29]. It was also lower than the critical internal temperature (assumed to be $39.7^{\circ} \mathrm{C}$ during laboratory experiments) and higher during competitive situations $[16,20,30,34]$; and lower than the core temperature usually described as being the critical temperature during self-paced exercise [34]. We therefore hypothesize that, despite a great loss in water, the participants were not at their core temperature "limit" during the trail runs. Moreover, we found a positive correlation between delta $\mathrm{T}_{\mathrm{gi}}$ and performance, with the participants showing the greatest increases in $\mathrm{T}_{\mathrm{gi}}$ being the fastest. This result is consistent with those noted by Lee et al. [14] and Noakes et al. [25] for road running and Parise and Hoffman [26] for long trail running. This finding is also likely related to the positive correlation between HR and performance in our study. 2 explanations can be suggested: (1) the participants of the present study were acclimated to living and training in a tropical climate and had made the appropriate adaptations, one of which being a 
lower core temperature during exercise [31], and (2) because these participants lived and trained in a tropical climate, they were aware of the stress induced by the climate [12] and thus applied "anticipatory regulation" $[15,35]$. This refers to the association observed between the rate of heat storage early in an exercise and the subsequent regulation of exercise intensity [36]: in this case, the participants of the present study may have regulated their intensity in order to limit the heat storage. This is reinforced by the lowest $\mathrm{HR}_{\text {mean }}$ noted in our studies along trails (i.e., $137-148 \mathrm{bpm}$ ) and those noted by Lee et al. (172 $\pm 7 \mathrm{bpm}$, [14]) or Byrne et al. (180 $\pm 7 \mathrm{bpm},[2])$. We could also hypothesize that the best runners, being more trained, were able to run at higher intensity, supporting a higher $\mathrm{T}_{\mathrm{gi}}$.

\section{Drinking ad libitum}

One of the aims of this study was to investigate the effect of a multiple-day race in tropical climate on the hydration status of self-hydrating participants. As noted by Lee et al. [14], a limited number of studies have accurately assessed fluid balance during mass-participation endurance races. The participants of the present study were free to drink as much water as they wanted, with the only limit being the maximum $4 \mathrm{~L}$ carried in their backpacks. The mean volume of $0.5{\mathrm{~L} . \mathrm{h}^{-1}}^{-1}$ ingested for a sweat loss of 1.1-1.8 L.h ${ }^{-1}$ clearly demonstrated the voluntary dehydration mostly observed in the best runners [27]. Despite this mathematically determined dehydrated status, we observed no significant change or abnormal values in osmolarity, $\mathrm{Na}^{+}$or $\mathrm{K}^{+}$. The only significant change was in CPK, which was increased at the end of the 6 days compared to the beginning, in relation to the muscle damage induced by the 6 consecutive days of trail running. It thus seems clear that these participants, despite great TBW loss (a mean $4.2 \mathrm{~L}$ ) associated with a mean $1.5 \mathrm{~L}$ of WI inducing a $2.6 \mathrm{~kg}$ loss (a mean $4 \%$ of body mass loss), did not present severe dehydration or heat-related illness while drinking ad libitum. Similar results have been described in the literature in both high-level marathoners [37] and standard runners [14]. Altogether, these findings reinforce the idea that ad libitum hydration is sufficient for endurance exercise in a hot environment $[14,24,37]$.

These results indicate that the participants of the present study were able to perform long-duration trail running over several days without presenting any heatstroke, perhaps because they were acclimated to the tropical climate $[10,12]$ and also because, as often proclaimed by Noakes [24], humans are adapted to perform in a hot environment.

To sum up, the present study demonstrated that, over the course of a trail race lasting several days in a tropical environment, well-trained acclimated runners who drank water ad libitum demonstrated no heat illness or severe dehydration. Moreover, high performance was associated with higher increases in $\mathrm{T}_{\mathrm{gi}}$ and greater TBW and BM losses per hour. Further studies are needed to investigate longer events and the strategies used to perform in such a climate, especially in non-acclimated runners.

\section{What does this paper add?}

This paper on the physiological adaptations during a multi-day trail race demonstrates that self-hydrated and acclimated runners do not suffer from dehydration or hyperthermia during multiple days of trail running in a tropical environment. It also shows that performance at the end of a multiple-day race is correlated with increased intestinal temperature and losses in both total body water and body mass in these runners, thereby providing evidence that these factors do not contribute to performance decreases in acclimated runners during multi-day trail races. Finally, because the participants in most sports should be advised to self-hydrate, even in tropical climate, adapted backpacks need to be developed to promote and facilitate self-hydration.

Conflict of interest: The authors have no conflict of interest to declare.

\section{References}

1 Beis LY, Wright-Whyte M, Fudge B, Noakes T, Pitsiladis YP. Drinking behaviors of elite male runners during marathon competition. Clin J Sport Med 2012; 22: 254-261

2 Byrne C, Lee JK, Chew SA, Lim CL, Tan EY. Continuous thermoregulatory responses to mass-participation distance running in heat. Med Sci Sports Exerc 2006; 38: 803-810

3 Cheuvront SN, Carter R, Castellani JW, Sawka MN. Hypohydration impairs endurance exercise performance in temperate but not cold air. J Appl Physiol 2005; 99: 1972-1976

4 Cheuvront SN, Carter R, Sawka MN. Fluid balance and endurance exercise performance. Curr Sports Med Rep 2003; 2: 202-208

5 Craig EN, Cummings EG. Dehydration and muscular work. J Appl Physiol 1966; 21: 670-674

6 Dugas JP. How hot is too hot?: Some considerations regarding temperature and performance. Int J Sports Physiol Perform 2010; 5: 559-564

7 Ely MR, Cheuvront SN, Roberts WO, Montain SJ. Impact of weather on marathon-running performance. Med Sci Sports Exerc 2007; 39: 487-493

8 González-Alonso J. Hyperthermia impairs brain, heart and muscle function in exercising humans. Sports Med 2007; 37: 371-373

9 González-Alonso J, Teller C, Andersen SL, Jensen FB, Hyldig T, Nielsen B. Influence of body temperature on the development of fatigue during prolonged exercise in the heat. J Appl Physiol 1999; 86: 1032-1039

10 Gosling CM, Gabbe BJ, McGivern J, Forbes AB. The incidence of heat casualties in sprint triathlon: The tale of two Melbourne race events. J Sci Med Sport 2008; 11: 52-57

11 Harriss DJ, Atkinson G. Ethical standards in sport and exercise science research: 2014 update. Int J Sports Med 2013; 34: 1025-1028

12 Hue $O$. The challenge of performing aerobic exercise in tropical environments: Applied knowledge and perspectives. Int J Sports Physiol Perform 2011; 6: 443-454

13 Hue O, Galy O, Blonc S, Hertogh C. Anthropometric and physiological parameters of performance in French West Indian monofin swimmers. Int J Sports Med 2006; 27: 605-609

14 Lee JK, Nio AQ Lim CL, Teo EY, Byrne C. Thermoregulation, pacing and fluid balance during mass participation distance running in a warm and humid environment. Eur J Appl Physiol 2010; 109: 887-898

15 Marino FE. Anticipatory regulation and avoidance of catastrophe during exercise-induced hyperthermia. Comp Biochem Physiol B Biochem Mol Biol 2004; 139: 561-569

16 Maron MB, Wagner JA, Horvath SM. Thermoregulatory responses during competitive marathon running. J Appl Physiol 1977; 42: 909-914

17 Maughan RJ. Distance running in hot environments: A thermal challenge to the elite runner. Scand J Med Sci Sports 2010; 20 (Suppl 3): 95-102

18 Maughan RJ, Otani H, Watson P. Influence of relative humidity on prolonged exercise capacity in a warm environment. Eur J Appl Physiol 2012; 112: 2313-2321

19 McCann DJ, Adams WC. Wet bulb globe temperature index and performance in competitive distance runners. Med Sci Sports Exerc 1997; 29: 955-961

20 Nielsen B, Hales JR, Strange S, Christensen NJ, Warberg J, Saltin B. Human circulatory and thermoregulatory adaptations with heat acclimation and exercise in a hot, dry environment. J Physiol 1993; 460: 467-485

21 Nielsen B, Kubica A, Bonnesen A, Rasmussen J, Stoklosa J, Wilk B. Physical work capacity after dehydration and hyperthermia. Scand J Sports Sci 1981; 3: 2-10

22 Noakes TD. Fluid replacement during exercise. Exerc Sport Sci Rev 1993; 21: 297-330 
23 Noakes TD. Maximal oxygen uptake: "Classical" versus "contemporary" viewpoints: A rebuttal. Med Sci Sports Exerc 1998; 30: 1381-1398

24 Noakes TD. Hydration in the marathon: Using thirst to gauge safe fluid replacement. Sports Med 2007; 37: 463-466

25 Noakes TD, Myburgh KH, du Plessis J, Lang L, Lambert M, van der Riet $C$, Schall $R$. Metabolic rate, not percent dehydration, predicts rectal temperature in marathon runners. Med Sci Sports Exerc 1991; 23: 443-449

26 Parise CA, Hoffman MD. Influence of temperature and performance level on pacing a $161 \mathrm{~km}$ trail ultramarathon. Int J Sports Physiol Perform 2011; 6: 243-251

27 Passe D, Horn M, Stofan J, Horswill C, Murray R. Voluntary dehydration in runners despite favorable conditions for fluid intake. Int J Sport Nutr Exerc Metab 2007; 17: 284-295

28 Pugh LG, Corbett JL, Johnson RH. Rectal temperatures, weight losses, and sweat rates in marathon running. J Appl Physiol 1967; 23: 347-352

29 Rae DE, Knobel GJ, Mann T, Swart J, Tucker R, Noakes TD. Heatstroke during endurance exercise: Is there evidence for excessive endothermy? Med Sci Sports Exerc 2008; 40: 1193-1204

30 Robinson S. Temperature regulation in exercise. Pediatrics 1963; 32: suppl 691-suppl 702
31 Saat M, Tochihara Y, Hashiguchi N, Sirisinghe RG, Fujita M, Chou CM Effects of exercise in the heat on thermoregulation of Japanese and Malaysian males. J Physiol Anthropol Appl Human Sci 2005; 24: 267-275

32 Sawka MN, Burke LM, Eichner ER, Maughan RJ, Montain SJ, Stachenfeld NS. American college of sports medicine position stand. Exercise and fluid replacement. Med Sci Sports Exerc 2007; 39: 377-390

33 Sawka MN, Noakes TD. Does dehydration impair exercise performance? Med Sci Sports Exerc 2007; 39: 1209-1217

34 Schlader ZJ, Stannard SR, Mûndel T. Exercise and heat stress: performance, fatigue and exhaustion-a hot topic. Brt J Sports Med 2011; 45: 3-5

35 Tucker R, Marle T, Lambert EV, Noakes TD. The rate of heat storage mediates an anticipatory reduction in exercise intensity during cycling at a fixed rating of perceived exertion. J Physiol 2006; 574: 905-915

36 Tucker $R$, Noakes TD. The physiological regulation of pacing strategy during exercise: A critical review. Br J Sports Med 2009; 43: e110.113 6/bjsm.2009.057562

37 Van Rooyen M, Hew-Butler T, Noakes TD. Drinking during marathon in extreme heat: a video analysis study of the top finishers in the 2004 Athens Olympics marathons. S Afr J Sports Med 2010; 3: 55-61

38 Voltaire B, Galy O, Coste O, Recinais S, Callis A, Blonc S, Hertogh C, Hue $O$. Effect of fourteen days of acclimatization on athletic performance in tropical climate. Can J Appl Physiol 2002; 27: 551-562 